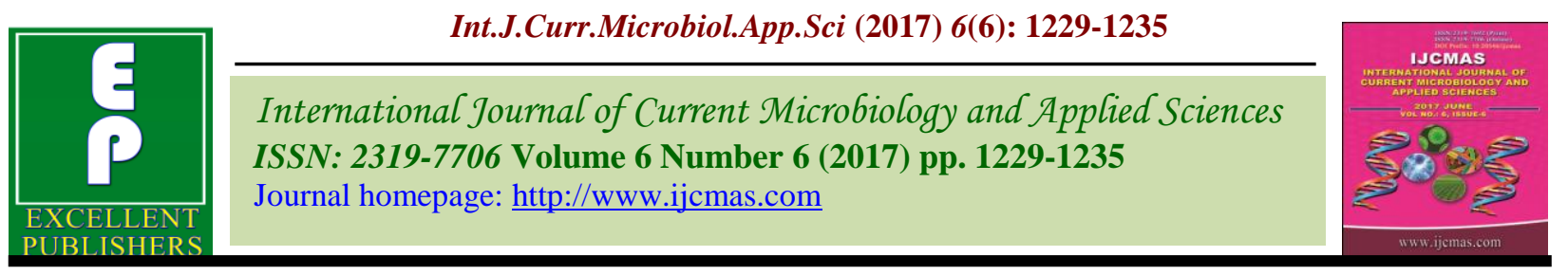

Original Research Article

https://doi.org/10.20546/ijcmas.2017.606.143

\title{
Effect of Age of Seedling and Split Application of Nitrogen on Productive Tiller and Stem Borer Incidence in Machine Transplanted Rice (Oryza sativa L.)
}

\author{
P. Rajesh $^{1 *}$, T. Ragavan ${ }^{1}$, R. Babu ${ }^{2}$, K. Balakrishnan ${ }^{3}$ and S. Thiyageswari ${ }^{4}$ \\ ${ }^{1}$ Department of Agronomy, ${ }^{2}$ Department of Farm Management, ${ }^{3}$ Department of Crop \\ Physiology, ${ }^{4}$ Department of Soils and Environment, Agricultural College and Research Institute, \\ Madurai, Tamil Nadu, India \\ *Corresponding author
}

A B S T R A C T

Keywords

Rice, Age of seedling, Nitrogen dose, Split application of $\mathrm{N}$, Productive tillers, Stem borer incidence.

Article Info

Accepted:

19 May 2017

Available Online:

10 June 2017
Field experiment was conducted at wetland of Agricultural College and Research Institute, Madurai, during the kharif and rabi season of 2016-17 to study the effect of age of seedling and split application of nitrogen in machine transplanted rice. The three seedlings viz., 14, 18 and 22 days old seedlings were transplanted to the main field by using rice transplanter and four levels of nitrogen were applied in the sub plots (120 kg ha ${ }^{-1} \mathrm{~N}$ in 3 equal splits and $150 \mathrm{~kg} \mathrm{ha}^{-1} \mathrm{~N}$ in 3,4 and 5 equal splits). The maximum number of productive tillers was recorded in 18 days old transplanted seedlings with $150 \mathrm{~kg} \mathrm{ha}^{-1} \mathrm{~N}$ in four splits than that of other treatment combinations. The higher stem borer incidence was recorded in transplanting of 18 days old seedlings with $150 \mathrm{~kg} \mathrm{ha}^{-1} \mathrm{~N}$ in three splits. The reduced stem borer infestation was increasing under the number of $\mathrm{N}$ splits machine transplanted condition.

\section{Introduction}

Rice (Oryza sativa L.) is the greatest stable diet and extensively grown cereal crop in the world and considered as the "global grain". About 90 per cent of rice grown in the world is produced and consumed only in Asian countries and it supplies 50 to 80 per cent calories of energy to Asian countries. Intensification of agriculture has provoked the complications of biotic stresses including insects, diseases and weeds on crops including rice. In productivity, India ranks $15^{\text {th }} 18^{\text {th }}$ among rice producing countries
(Anonymous, 2010). In rice cultivation nitrogen nutrition plays a key role in rice production as it is required in huge amount. It is the essential component of cell molecules including chlorophyll, nucleic acids, amino acids, ATP and a number of plant hormones. It is an important regulator involved in many biochemical processes such as protein synthesis, carbon metabolism and amino acid metabolism. Proper management of crop nutrition is of huge importance as judicious and proper use of fertilizers makes 
remarkable improvement in the yield and quality of rice. Timing and rate of nitrogen application are critical in terms of their impacts on yield by incidence of pest and diseases. As nitrogen increases plant height, leaf size, number of panicles, number of spikelets and filled spikelets per panicle. Nitrogen supply must be available according to the needs of the plant for optimal yield. The occurrence of more than one pest species in field is, however, common place rather than an exception. In such a situation, individual pests may be below their respective EILs, but pests may jointly inflict economic loss (Palis et al., 1990). There are three possible outcomes of combined pest infestations on crop yield viz., no interaction, greater than additive (synergistic) interactions and less than additive (antagonistic) interactions (Lamp et al., 1985). When interactions occur, the effects of combined pest populations are greater or less than the summed effects of each single-pest infestation (Johnson, 1990).

Rice crop is prone to stress throughout crop growth period due to onslaught by the different pest and disease. Nutrition management is one of the most important practices for high production system, but improper nutrition management may affect response of rice to pests, as well as development pattern of pest populations due to the change of environments. The understanding of impacts of nutrition management on interactions between rice and pests is a basis to stimulate high yield production system. Most pest management methods used by farmers can be considered as soil fertility management strategies and vice versa. Incidence of yellow stem borer on rice was reported throughout the country with a varied level of severity and the reported yield losses ranged from 3 to 65 per cent (Ghose et al., 1960). Hence, keeping this in view the present investigation was conducted to the study the combined effect of age of seedlings and nitrogen management on stem borer incidence in rice.

\section{Materials and Methods}

Field experiment was conducted at wetland of Agricultural College and Research Institute, Madurai, during the kharif and rabi season of 2016-17. The soil of the experimental site was neutral in reaction with $\mathrm{pH}$ of 7.3 and organic carbon content present in the soil was 0.30 per cent. The fertility of the soil was found to be low in available nitrogen (244.4 $\mathrm{kg} \mathrm{ha}^{-1}$ ) medium in phosphorus (19.3 $\left.\mathrm{kg} \mathrm{ha}^{-1}\right)$ and medium in potassium $\left(238.0 \mathrm{~kg} \mathrm{ha}^{-1}\right)$. The experiment was laid out in a Split Plot design with three replications. The experiment consisted of three age of seedlings allotted to the main plot $\mathrm{A}_{1}$ (14 day old seedlings), $\mathrm{A}_{2}$ (18 day old seedlings) and $A_{3}$ (22 day old seedling) and four nitrogen level, $\mathrm{N}_{1}$ Recommended dose 120:40:40 $\mathrm{kg} \mathrm{ha}^{-1}$ with three equal splits viz., at basal, active tillering and flowering stages, $\mathrm{N}_{2}$ (Extra dose, $125 \%$ $\mathrm{N}: 150: 40: 40 \mathrm{NPK} \mathrm{kg} \mathrm{ha}{ }^{-1}$ ) were also applied three equal splits viz., at basal, active tillering and flowering stages, $\mathrm{N}_{3}$ (Extra dose, $125 \%$ $\mathrm{N}: 150: 40: 40 \mathrm{NPK} \mathrm{kg} \mathrm{ha}{ }^{-1}$ ), with four equal splits viz., Basal, 20, 40 and 60 days after transplanting, $\mathrm{N}_{4}$ (Extra dose, $125 \% \mathrm{~N}$ : 150:40:40 NPK kg ha ${ }^{-1}$ ) applied at basal, 15, 30,45 and 60 days after transplanting. The 14, 18 and 22 days old seedlings were kept from the nursery and transplanted in the main field was done same day by using Kubota model 6 row rice transplanter (Model: Kubota NSPU-68C). The row to row spacing of transplanter is $30 \mathrm{~cm}$ and hill to hill spacing of $15 \mathrm{~cm}$. the planting planting speed is 0 to $1.62 \mathrm{~m} \mathrm{sec}^{-1}$. The given NPK, Nitrogen $(\mathrm{N})$, phosphorous $\left(\mathrm{P}_{2} \mathrm{O}_{5}\right)$ and potash $\left(\mathrm{K}_{2} \mathrm{O}\right)$ were applied in the form of urea, single super phosphate (SSP) and muriate of potash (MOP), respectively as per the treatment schedule. 
The prevalence stem borer (Scirpophaga incertulas) population count were taken by collecting injured plants and recorded based on the symptoms of dead hearts recorded at reproductive stage and rated as rating scale given by Kavitha and Dharna reddy (2015). Stem borer damage data were arcsin transformed and mean value was compared using the least significant difference (LSD) at 0.05 significance level. The per cent of dead hearts and white heads was calculated as per the following formula:

No. of dead hearts counted Percent $(\%)$ dead hearts $=$

Total no. of tillers counted

\section{Results and Discussion}

\section{Productive tillers hil $^{-1}$}

The age of seedlings and split application of nitrogen significantly influenced the productive tillers in the machine transplanted rice (Table 1). Among the age of seedlings, 18-days old seedlings significantly registered higher number of productive tillers at harvest (21.1 and 22.0) and it was followed by 22 days old seedling at harvest (19.5 and 18.1) during the kharif 2016 and rabi 2016-17, respectively (Table 1 ). The lower productive tillers was recorded under 14 days old seedling at harvest (16.1 and 15.4) during kharif 2016 and rabi 2016-17. The increase in productive tillers under 18 days old seedlings might be due to proper utilization of all the available and terrestrial growth resources and vigorous seedling which may be better establishment, translocation of photosynthetic from source to sink which may result higher yield attributes under machine transplanting. Another possible reason is ability of the seedlings to withstand shorter period of transplanting shock and faster resumption of the rate of phyllochron development over younger and older seedlings (Yamamoto et al., 1998).

Nitrogen level played an important role in increasing number of productive tillers in machine transplanted rice. The results showed that the number of productive tillers hill $^{-1}$ increased gradually due to increasing number of splits and nitrogen application up to N 125 per cent. Among the nitrogen splits, 125 per cent nitrogen with four equal splits recorded the maximum number of productive tillers hill $^{-1}$ (21.4 and 20.7) and this was followed by 125 per cent nitrogen with five equal splits. The lesser number of productive tillers hill ${ }^{-1}$ (16.5 and 15.9) was recorded in 100 per cent nitrogen with three equal splits on both the seasons of kharif 2016 and rabi 2016-17, respectively. This might be attributed to the higher availability of macro nutrients, which plays a vital role in cell division. Increase in tiller production might also probably be due to the greater supply of nutrients with efficient utilization for cell multiplication and enlargement and formation of nucleic acids and other vitally important organic compounds in the cell sap (Chandravanshi and Singh, 1974; Simons, 1982). Mirza et al., (2010) reported increase in number of tillers due to increased fertilizer levels.

The interaction between the various age of seedlings and split application of nitrogen was significant. Among the interaction effect, 18 days old seedling and 125 per cent nitrogen application with four equal splits registered higher number of productive tillers hill ${ }^{-1}$ (24.3 and 23.1) and it was followed by 18 days old seedling with $125 \%$ nitrogen application with five equal splits during kharif 2016 and rabi 2016-17, respectively. The lesser number of productive tillers hill ${ }^{-1}$ was recorded (14.2 and 12.2) in the combination of 14 days old seedlings and 100 per cent nitrogen application with three equal splits. The Vigorous root growth and better access to the 
nutrients and moisture put forth much tiller into more productive one. The reason for reduction in productive tillers with aged seedlings is attributed to the phyllochron effect. Similar finding was reported by Chandrakar et al., (2008) who opined that number of productive tillers was reduced with progress in age of seedlings. The increased in effective tillers hill ${ }^{-1}$ observed for this treatments were due to favorable root growth and higher mobility of nitrogen in soil solution and its absorption by plant root. The results are in conformity with earlier findings of Tripathi and Jaishwal (2006); Bera and Pramanik (2010).

Table.1 Effect of age of seedlings and split application of nitrogen on productive tiller hill ${ }^{-1}$ in machine transplanted rice during Kharif 2016 and Rabi 2016-17

\begin{tabular}{|c|c|c|c|c|c|c|c|c|c|c|}
\hline \multicolumn{5}{|c|}{ No. of Productive tillers hill ${ }^{-1}$ during Kharif 2016} & \multicolumn{6}{|c|}{ No. of Productive tillers hill ${ }^{-1}$ during Kharif 2016-17 } \\
\hline & N1 & $\mathbf{N 2}$ & N3 & N4 & Mean & N1 & $\mathbf{N 2}$ & N3 & N4 & Mean \\
\hline A1 & 14.2 & 15.4 & 18.1 & 16.8 & 16.1 & 12.2 & 14.9 & 17.6 & 16.9 & 15.4 \\
\hline A2 & 18.4 & 19.6 & 24.3 & 21.9 & 21.1 & 20.4 & 21.6 & 23.1 & 22.7 & 22.0 \\
\hline \multirow[t]{2}{*}{ A3 } & 16.7 & 18.4 & 21.8 & 21.0 & 19.5 & 14.9 & 16.8 & 21.4 & 19.3 & 18.1 \\
\hline & 16.5 & 17.8 & 21.4 & 19.9 & & 15.9 & 17.8 & 20.7 & 19.6 & \\
\hline \multicolumn{2}{|c|}{ Source } & \multicolumn{3}{|c|}{ SEd } & \multicolumn{2}{|l|}{ CD } & \multicolumn{2}{|c|}{ SEd } & \multicolumn{2}{|c|}{ CD } \\
\hline \multicolumn{2}{|c|}{ A } & \multicolumn{3}{|c|}{0.47} & \multicolumn{2}{|l|}{1.31} & \multicolumn{2}{|c|}{0.47} & \multicolumn{2}{|c|}{1.32} \\
\hline \multicolumn{2}{|c|}{$\mathbf{N}$} & \multicolumn{3}{|c|}{0.27} & \multicolumn{2}{|l|}{0.57} & \multicolumn{2}{|c|}{0.38} & \multicolumn{2}{|c|}{0.79} \\
\hline \multicolumn{2}{|c|}{$\mathbf{A X N}$} & \multicolumn{3}{|c|}{0.62} & \multicolumn{2}{|l|}{1.55} & \multicolumn{2}{|c|}{0.74} & \multicolumn{2}{|c|}{1.76} \\
\hline \multicolumn{2}{|c|}{ NXA } & \multicolumn{2}{|c|}{0.47} & & \multicolumn{2}{|l|}{0.99} & \multicolumn{2}{|c|}{0.65} & \multicolumn{2}{|c|}{1.37} \\
\hline
\end{tabular}

Main plot (Age of seedling) Sub plot (Nitrogen splits)

$\mathrm{A}_{1}-14$ day old seedlings $\mathrm{N}_{1}-\mathrm{RDN}$ (Basal, Active tillering, Panicle initiation)

$\mathrm{A}_{2}-18$ day old seedlings $\mathrm{N}_{2}-\mathrm{N} 125 \%$ (Basal, Active tillering, Panicle initiation)

$\mathrm{A}_{3}-22$ day old seedlings $\mathrm{N}_{3}-\mathrm{N} 125 \%$ (4 equal Splits (1/4) at Basal and 20, 40, 60 DAT)

$\mathrm{N}_{4}-\mathrm{N} 125 \%$ (5 equal Splits $\left({ }_{1 / 5}\right)$ at Basal and 15, 30, 45, 60 DAT)

Table.2 Effect of age of seedlings and split application of nitrogen on stem borer incidence (\%) in machine transplanted rice during Kharif 2016 and Rabi 2016-17

\begin{tabular}{|c|c|c|c|c|c|c|c|c|c|c|}
\hline \multicolumn{6}{|c|}{ Stem borer incidence (\%) during Kharif 2016} & \multicolumn{5}{|c|}{ Stem borer incidence (\%) during Rabi 2016-17 } \\
\hline & N1 & $\mathbf{N 2}$ & N3 & N4 & Mean & N1 & $\mathbf{N} 2$ & N3 & N4 & Mean \\
\hline A1 & 5.6 & 7.9 & 2.6 & 2.4 & 4.6 & 6.8 & 8.4 & 3.1 & 2.8 & 5.3 \\
\hline $\mathbf{A 2}$ & 8.2 & 9.0 & 3.7 & 3.7 & 6.2 & 9.2 & 10.3 & 4.6 & 3.7 & 7.0 \\
\hline \multirow[t]{2}{*}{ A3 } & 6.7 & 8.3 & 3.3 & 3.7 & 5.5 & 7.1 & 9.2 & 4.1 & 4.0 & 6.1 \\
\hline & 6.8 & 8.4 & 3.2 & 3.3 & & 7.7 & 9.3 & 3.9 & 3.5 & \\
\hline \multicolumn{2}{|c|}{ Source } & \multicolumn{3}{|c|}{ SEd } & \multicolumn{2}{|l|}{ CD } & \multicolumn{2}{|c|}{ SEd } & \multicolumn{2}{|c|}{ CD } \\
\hline \multicolumn{2}{|c|}{ A } & \multicolumn{3}{|c|}{0.09} & \multicolumn{2}{|l|}{0.25} & \multicolumn{2}{|c|}{0.17} & \multicolumn{2}{|c|}{0.47} \\
\hline \multicolumn{2}{|c|}{$\mathbf{N}$} & \multicolumn{3}{|c|}{0.09} & \multicolumn{2}{|l|}{0.18} & \multicolumn{2}{|c|}{0.12} & \multicolumn{2}{|c|}{0.25} \\
\hline \multicolumn{2}{|c|}{ AXN } & \multicolumn{3}{|c|}{0.16} & \multicolumn{2}{|l|}{0.37} & \multicolumn{2}{|c|}{0.25} & \multicolumn{2}{|c|}{0.60} \\
\hline \multicolumn{2}{|c|}{ NXA } & \multicolumn{2}{|c|}{0.15} & & \multicolumn{2}{|l|}{0.31} & \multicolumn{2}{|c|}{0.21} & \multicolumn{2}{|c|}{0.44} \\
\hline
\end{tabular}

Main plot (Age of seedling) Sub plot (Nitrogen splits)

$\mathrm{A}_{1}-14$ day old seedlings $\mathrm{N}_{1}-\mathrm{RDN}$ (Basal, Active tillering, Panicle initiation)

$\mathrm{A}_{2}-18$ day old seedlings $\mathrm{N}_{2}-\mathrm{N} 125 \%$ (Basal, Active tillering, Panicle initiation)

$\mathrm{A}_{3}-22$ day old seedlings $\mathrm{N}_{3}-\mathrm{N} 125 \%$ (4 equal Splits (1/4) at Basal and 20, 40, 60 DAT)

$\mathrm{N}_{4}-\mathrm{N} 125 \%$ (5 equal Splits (1/5) at Basal and 15, 30, 45, 60 DAT) 


\section{Stem borer incidence in machine transplanted rice}

The present result was clearly shows stem borer incidence (\%) was markedly influenced by the age of seedlings during both the seasons (Table 2). The lower stem borer incidence (4.6 and $5.3 \%$ ) was recorded in 14 days old age seedlings. This was followed by 22 days old age seedlings during Kharif 2016 and Rabi 2016-17, respectively. The highest stem borer incidence of 6.2 and 7.0 per cent was registered with 18 days old age seedling. Results revealed that the infestation of rice stem borer per cent was significantly higher in transplanted at right age of seedling in machine transplanted condition. This could be due to the better seedling establishment, profuse tilllering and crop growth habits which favour the stem borer incidence. This entails that later stages of rice plantings were more pronounced to exceedingly stem borer infestation than earlier or off season sowing. Similar result was also reported by Suharto and Usyati (2005). The study implied that adjustment of planting time is the most feasible effort to reduce stem borer infestation because none of the rice cultivars tested was able to minimize damage under heavily infestation of yellow stem borer. Similar findings of Abraham et al., (1992) back up the present work stating that the activity of stem borer of first generation appeared after transplanting. Being a monophagous pest, Srivastava et al., (2003) reported that the population of stem borer increased in subsequent generation caused reasons for successive increases in pest population. Similarly, present results revealed that the stem bore incidence in rabi season which recorded slightly higher than kharif season.

Among the different nitrogen level and number of split application significantly influenced in the stem borer incidence during both the seasons of Kharif 2016 and Rabi
2016-17. The lower stem borer incidence of 3.2 and 3.9 per cent was recorded $125 \%$ nitrogen with four equal splits during both the season of Kharif and Rabi, respectively. The higher stem borer incidence was significantly registered with 125 per cent nitrogen 3 equal splits (8.4 and 9.3\%) during both the seasons, respectively. Application of higher doses of fertilizer induces metabolic activity of plants, increases the girth and internodal length of the stem making it more spacious for larval boring and subsequent accommodation and hence imparts greater survival value to the larvae (Chakraborty, 2011). This could might be due to the higher dose of nitrogen with minimum splits can facilitate the initial crop growth and ultimately a favors stem borer in the machine transplanted condition.

The interaction of different age of seedling with split application of nitrogen significantly influenced the incident level of stem borer in machine transplanted rice. The lower stem borer (2.4 and 2.8\%) was observed in 14 days old seedling with 125 per cent nitrogen five equal splits during both the seasons. The higher stem borer incidence (9.0 and 10.3\%) was found in 18 days old seedling with 125 per cent nitrogen in three equal splits. This was agreement with earlier findings of (Kulagod et al., 2009). Nishida (1975) and Yamamoto et al., (1998) stated that nitrogenous fertilizers contributed to the thickness of the rice canopy which created humid and shaded microenvironment conducive for the insect to multiply and this could be due to the better establishment of right age of seedling with lessor transplanting shock in machine transplanted condition.

The findings of the study revealed that, number of productive tillers was significantly influenced by the 18 days old seedlings with 125 percent of nitrogen application in four equal splits. However, the stem borer incidence was higher with 18 days old 
seedling but not much affected the productive tillers. The incidence of stem borer was reduced with application of nitrogen upto four equal number of splits in machine transplanted rice ecosystem. Thereby can be reduced the stem borer incidence and yield loss at certain level by the effective cultural practices.

\section{References}

Abraham, C.C., B. Thomas, K. Karunakaran, R. Gopalkrishnan. 1992. Effect of planting season and the associated weather conditions on the incidence of the rice stem borer. Agric. Res. J., 19: 141-151.

Altieri, M.A., C.L. Nicholls. 2003. Soil fertility management and insect pests: harmonizing soil and plant health in agroecosystems. Soil Tillage Res., 72: 203-211.

Anonymous. 2004. The System of Rice Intensification - SRI, Variations in SRI practices.

Anonymous. 2010. The Hindu Survey of Indian Agriculture. The Hindu, Chennai, India.

Bera, A.K. and K. Pramanik. 2010. Response of rice hybrid to different source of phosphorus and homobrassinolide under lateritic zone of West Bengal. In: Abstract of National Symposium on Sustainable rice production system under changed climate, 27th to 29th November, 2010 at Central Rice Research Institute, Cuttack, Orissa, India. Pp- 55.

Chakraborty, K. 2011. Influence of inorganic $\mathrm{n}$ fertilizer on plant characters, yield generation and the incidence of yellow stem borer Scirpophaga incertulas, walker in the field of local scented paddy cultivar tulaipanji. Int. J. Appl. Biol. Pharm. Technol., Page: 264-273.
Ghose, R.L.M., M.B. Ghatge, and V. Subramanyan. 1960. Pests of Rice. Indian Council of Agricultural Research, New Delhi, pp.248-257.

Johnson, K.B. 1990. Assessing multiple pest populations and their effects on crop yield. In: Crop Loss Assessment in Rice. International Rice Research Institute, Manila, Philippines, pp. $203 \mathrm{e} 214$

Katayama, T. 1951. Ine mugo no bungetsu kenkyu (Studies on tillering in rice, wheat and barley). Yokendo Publishing, Tokyo.

Kavitha, K. and K.D. Reddy. 2015. Screening techniques for different insect pests in crop plants. Int. J. Biores. Stress Manag., 3(2): 188-195.

Kulagod, S.D., M.G. Hegde, G.V. Nayak, A.S. Vastrad and P.S. Hugar. 2011. Influence of fertilizer on the incidence of insect pests in paddy. Karnataka $J$. Agric. Sci., 24(2): 241-243.

Lamp, W.O., K.V. Yeargan, R.F. Nonis, C.G. Summers and D.G. Gilchrist. 1985. Multiple pest interactions in alfalfa. In: Frisbie, R.E., Adkinsson, P.L. (Eds.), CIPM - Integrated Pest Management on Major Agricultural Systems, vol. 1616. Texas Agricultural Experiment Station Miscellaneous Publication, College Station, Texas, pp. 345e364.

Nishida, T. 1975. Causes of brown plant hopper out-break. Rice Ent. Newsltr., (2): 38 .

Palis, F., P.L. Pingali and J.A. Litsinger. 1990. A multiple-pest economic threshold for rice-a case study in the Philippines. In: Crop Loss Assessment in Rice. International Rice Research Institute, Manila, Philippines, pp $229 \mathrm{e} 242$.

Singh, K.K., S.K. Yadav, B.S. Tomaro, J.N. Singh and P.K. Singh. 2004. Effect of seedlings age on seed yield and seed 
quality attributes in rice cv. Pusa Basmati-1. Seed Res., 32(1): 5-8.

Srivastava, S.K., M. Salim, A. Rehman, A.

Singh, D.K. Garg, C.S. Prasad, B.K. Gyawali, S. Jaipal and N.Q. Kamal. 2003. Stem Borer of Rice-Wheat Cropping System: Status, Diagnosis, Biology and Management. Rice-Wheat Consortium Bulletin Series, Rice-Wheat Consortium for the Indo-Gangetic Plains, New Delhi, India, p. 273.
Tripathi, H.P. and L.M. Jaishwal. 2006. Effect of nitrogen yield attributes and yield of rice hybrids under irrigated conditions. Oyza, 43(3): 249-250.

Yamamoto, Y., A. Ikejiri and Y. Nitta. 1998. Characteristics of taking root of rice nurseling seedling in relation to the changes of some noganic and organic constituents after transplanting. Jpn. J. Crop Sci., 67: 20-25.

\section{How to cite this article:}

Rajesh, P., T. Ragavan, R. Babu, K. Balakrishnan and Thiyageswari, S. 2017. Effect of Age of Seedling and Split Application of Nitrogen on Productive Tiller and Stem Borer Incidence in Machine Transplanted Rice (Oryza sativa L.). Int.J.Curr.Microbiol.App.Sci. 6(6): 1229-1235. doi: https://doi.org/10.20546/ijcmas.2017.606.143 